DOI 10.18551/rjoas.2019-06.13

\title{
INDONESIA CANTEEN SANITATION POLICY IMPLEMENTATION IN COLLEGE CAMPUS AS A STEP TO OPTIMIZING THE PUBLIC HEALTH SECTOR
}

\author{
Nirawati Lia* \\ Department Business of Administration, UPN “Veteran” Jawa Timur, Indonesia \\ Kriswibowo Arimurti \\ Department of Public Administration, UPN “Veteran” Jawa Timur, Indonesia \\ Nurani Fesdila Putri \\ Department of Food Technology, UPN “Veteran" Jawa Timur, Indonesia \\ *E-mail: lia.upnjatim@gmail.com
}

\begin{abstract}
Environmental sanitation is very important for a canteen as the a part of world of education, especially at the university level, to maintain the public health in an effort to prevent the occurrence of health problems due to environmental factors that can potentially harm health. This is done with the aim that the implementation of health development is to increase awareness, willingness and ability to live healthy for everyone in order to realize the optimal degree of public health. Given that health problems are one of the most important needs for efforts to achieve optimization of the public health sector. The sanitation development process aims to increase awareness, willingness and ability to live healthy for everyone in order to realize the highest degree of public health, as an investment for the development of socially and economically productive human resources. This paper was compiled with a literature review method with the aim of knowing the urgency of canteen sanitation policies within the campus in a theoretical manner and the process of policy formulation. Therefore, the importance of implementing canteen sanitation policies in an effort to optimize the public health sector must be carried out properly so that the impact of lack of attention to canteen sanitation within the university or campus is no longer happening.
\end{abstract}

\section{KEY WORDS}

Implementation studies, canteen sanitation, food service management, public health, catering sanitation.

The problem of processing and serving food is something that must get special attention in the application of overall health. This is because food is one of the basic human needs that directly plays a role in improving human health and well-being. For this reason, food must meet health standards, which are safe, healthy, nutritious and do not cause interference with the disease (Chusna, 2012). In the world of education, especially in universities, there are certain food providers in it, we often know the term canteen. As a food provider dealing directly with canteen service users, of course, there are many problems that they face, one of which is in terms of food hygiene and landfills that are not helped, this is the most important factor in the discussion of canteen sanitation in the educational environment. Because the cleanliness of a food can affect the health of the buyer or user of the canteen, if it is wrong in the process of handling sanitation it can cause a slum and unhygienic impression, this is what makes many health problems faced by canteen service users.

Environmental health development is an integral and most important part of national development. The purpose of holding health development is to increase awareness, willingness and ability to live healthy for everyone to realize optimal public health degrees. Article 48 of the Health Law No. 36 of 2009 states that efforts to administer health are carried out through family health activities, nutrition improvement, food and beverage supervision, environmental health, occupational health, mental health, eradication of diseases, health 
recovery, counseling public health, supervision of pharmaceuticals and medical devices, additive supervision, school health, sports health, traditional medicine and eye health. One important component in carrying out a health-care business is through healthy canteen services. Canteen/cafeteria is a business (place) that is carried out by schools to provide services to students or other school elements that need healthy food and drinks so that teaching and learning activities in schools can achieve their goals to the maximum (Ulfatin \& Triwiyanto, 2015).

In 2008 the Indonesia Food and Drug Supervisory Agency (BPOM, 2008) reported 197 cases of food poisoning throughout Indonesia with 9022 sufferers, which included 8943 sick / treated people and 79 who died. Judging from the incidence of outbreaks of food poisoning it was concluded that $85(43.15 \%)$ cases had not been identified, $54(27.41 \%)$ cases were due to microbiology, $37(18.78 \%)$ cases were due to chemicals and $21(10.66 \%)$ cases of no samples. The profile of the proportion of morbidity in the case of food poisoning outbreaks in 2008 can be concluded that the highest number of cases was reported in West Java as many as 3166 (35.40\%), Central Java 1240 (13.87\%) and Central Kalimantan as much as $860(9.62 \%)$. This incident shows that more than $25 \%$ of poisoning cases are caused by microbiological activity which is very likely due to poor sanitation.

\section{LITERATURE REVIEW}

The environment is one variable that gets special attention in assessing public health conditions. One environment that must be considered is the educational environment, where there are young people and young people who will become the next generation of the nation. Therefore, the level of health needs to be fostered and improved. One of these health efforts is maintaining canteen cleanliness in the educational environment (Sari, 2013). Environmental sanitation is one indicator of an environmental health status that includes housing, sewage, clean water supply and so on. Environmental sanitation can also be interpreted as an activity aimed at improving and maintaining basic environmental conditions that affect human health. These conditions include: 1) supply clean and safe water; 2) disposal of waste from efficient animals, humans, and industries; 3) food protection from biological and chemical contamination; 4) clean and safe air; 5) a clean and safe house (Oihuwal, 2012).

On the other side, the Higher Education Campus is one of the educational institutions that have the facility for selling foods in the form of a canteen specifically reserved for students, lecturers, and administrative staff. The canteen is a facility provided to meet the food needs of campus residents. The cleanliness of the canteen as a food processing place at the university level aims to facilitate the fulfillment of food and beverage needs for students, lecturers and administrative staff so that the fulfillment of food and beverage needs is expected to be protected and guaranteed to create a productive work spirit. Aside from being a place for processing food, cooking and making food, which is then served to consumers, the canteen can also be a place for the spread of disease through its food and drink. Thus food and beverages sold in canteens have the potential to cause disease-related illnesses if not managed and handled properly (Mukono, 2000).

Given that health problems are a very complex problem, which is interrelated with other problems outside of health itself. Supriadi \& Chandra (2018) argue that sanitation is very important to maintain the environmental health of an environment to prevent the occurrence of health problems due to environmental factors that can potentially harm health. Environmental sanitation is an effort to achieve a healthy environment through controlling physical environmental factors, especially those that have a detrimental impact on the physical development of health and human survival (Utami, Thoha, \& Nugraheni, 2018). Likewise, solving public health problems is not only seen in terms of its health but must be seen from all aspects that influence these health problems.

A poor sanitation environment will harm health. Various types of diseases can arise because a poor sanitizing environment is a source of various types of diseases. So that we avoid various diseases, the environment must always be maintained sanitation, especially 
the canteen as a food processing place at each university. Canteen sanitation is a health effort carried out by maintaining and protecting the cleanliness of the canteen environment from various risk factors that can pollute the canteen environment. For example, providing clean water for handwashing purposes, providing trash bins to accommodate garbage so that it is not disposed of carelessly, the condition of the building and the canteen yard must be clean and neat so that the user's comfort and safety are maintained and free of vectors.

The requirements for canteen sanitation are explained in the Regulation of the Minister of Health of the Republic of Indonesia Number (Kepmenkes) 1096 / Menkes / PER / VI / 2011 , concerning sanitation hygiene in the catering service. Sanitation is the most important part of the food processing process that must be carried out properly. Sanitation can be defined as an effort to prevent disease by eliminating or regulating environmental factors related to the chain of disease transfer. (Rahmawati, Farahdiba, Alfan, \& Adhly, 2018).

Contamination can occur in food if not processed properly. The problem that often arises in society is the quality and quantity of food production. Therefore, food as a very important factor for human life in addition to fulfilling in terms of nutrition and attractive appearance, food must also be safe for consumption, which is free from all forms of contaminants that can harm consumers. The potential for food to be contaminated with hazardous substances and become a source of disease transmission increases if the handling process is consumed by the public not paying attention to hygiene and sanitation. The canteen at the university has an important role to fulfill the needs of its people for food while on campus. In general, foods sold in canteens have very diverse variations, with prices relatively cheap and easy to reach. (Nugroho \& Yudhastuti, 2014). According to Nadiawati (2013) "Hygiene is a science that studies health. Hygiene is closely related to individuals, food, and drinks because it is a condition for achieving health status. Moderate sanitation according to $\mathrm{WHO}$ is an effort to supervise several physical environmental factors that affect humans, especially on things that have detrimental effects on physical development, health, and survival.

\section{RESULTS AND DISCUSSION}

Public space has potential as a place for disease transmission, environmental pollution, or other health problems. Monitoring or inspection of public places is carried out to create clean public places to protect public health from the possibility of transmission of diseases and other health problems. Public places or facilities that are obliged to carry out environmental sanitation, among others, public places or public facilities that are managed commercially. (Wati, 2013). Health awareness is one of the most important needs for efforts to achieve healthy living skills for everyone. For achieving this aim, it is necessary to make the best efforts by the government to include improvements; prevention; healing; and recovery efforts that are comprehensive, integrated and sustainable. This is reasonable because the program policies in the health sector are quite extensive and require serious attention, therefore, this task is not only the responsibility of the government but also all levels of society. (Gasim, 2015). The Long Term Development Plan / RPJP (2005-2024) focuses on health development towards the promotion and preventive health efforts. One of the programs of the Indonesian Ministry of Health (Kemenkes) in the development plan is the Gerakan Hidup Sehat (Germas) / Healthy Life Movement. In this period, The Germas is focused on: Doing physical activities, Eating vegetables and fruits, Regularly checking the health and providing healthy food not only for accelerating nutrition improvement but also for achieving healthy people. The Germas program is expected to improve everyone's knowledge, awareness, willingness and ability to live healthily. (Kartika, 2017)

Based on Law No. 36 of 2009 concerning health, health development aims to increase awareness, willingness and ability to live healthy for everyone to realize the highest degree of public health, as an investment for the development of socially and economically productive human resources. Health development is directed at increasing awareness, willingness and the ability to live healthily for everyone so that the highest level of public health can be realized. In accordance with the vision and mission of health development 
towards Healthy Indonesia 2015-2019 which aims to create a healthy society that is independent and equitable, then the implementation must touch all levels of society and all age groups including elementary school students to students in the world of higher education (Kepmenkes, 2015 in Jaya Saputra, 2016). One important component in carrying out educational health efforts is through healthy canteen services. Canteen/cafeteria is a business place that is carried out by education services to provide services to students or other school elements that need healthy food and drinks so that teaching and learning activities in places education can achieve their goals to the maximum (Kusmintardjo, 1993).

Decree of the Republic of Indonesia Health Minister (Kep.Menkes) no. 1429 of 2006, concerning Guidelines for Implementing School Environmental Health, mentioning environmental health requirements covering several aspects including aspects of school canteen building and school sanitation facilities. The school canteen must have a good sanitation system because the canteen is the place where food is consumed by students. If the canteen sanitation system is not good, then the school canteen can be an intermediary in the emergence of health problems caused by food. Meanwhile, school sanitation facilities include the provision of clean water, toilets, wastewater disposal facilities, and waste disposal facilities. This school sanitation facility must meet the prescribed health requirements to support the implementation of environmental health in schools and prevent the transmission of disease in the school environment. As an educational institution, environmental health standards on higher education campuses can also adopt the same public policies.

According to Nugroho \& Yudhastuti (2014), the problems that often arise in the community are the quality and quantity of food production. Therefore, food as a very important factor for human life in addition to fulfilling in terms of nutrition and attractive appearance, food must also be safe for consumption, which is free from all forms of contaminants that can harm consumers. The potential for food to be contaminated with hazardous substances and become a source of disease transmission increases if the handling process is consumed by the public not paying attention to hygiene and sanitation. Restructuring efforts on canteen hygiene and sanitation have also been regulated in the regulation of the Indonesian health minister (Kepmenkes) No. 1098 / MENKES / PER / VII / 2003 concerning hygiene requirements for restaurant and restaurant sanitation. Where the canteen is one type of catering business that provides food, especially in an institution both educational institutions, government, and companies. Whereas sanitation can be defined as an effort to prevent disease by eliminating or regulating environmental factors related to the disease transfer chain. Sanitation science is the application of principles that will help improve, maintain, or restore good health to humans. Concerning food processing, sanitation is the creation or maintenance of conditions that can prevent food contamination or the occurrence of diseases caused by food. Or in other words, sanitation is an effort to reduce the number of seeds of disease contained in food ingredients in such a way that the degree of human health can be perfectly maintained (Nadiawati, 2013).

According to Oihuwal (2012), there are 4 (four) important things which are the principles of food hygiene and sanitation including the healthy and clean behavior of people who manage food, food sanitation, equipment sanitation, and food processing sanitation. All of that can be contaminated with microbes because of several things, including using a dirty cloth to clean the table, clean furniture, and others, and food stored without being closed so that insects and mice can reach it as well as sick food processors or disease careers. Meanwhile according to Blum in N. Sari, Irnawati, \& Indra, (2013) that health degrees are influenced by 4 (four) factors, namely: environment, behavior, health services and offspring. Based on these four factors, in developing countries, environmental factors and behavioral factors have a very large role in addition to other factors to improving the degree of public health. Both of these opinions can complement each other to perfect the factors that can influence the level of environmental health.

Good hygiene of food and beverage sanitation needs to be supported by environmental conditions and good sanitation facilities. These facilities include: (1) the availability of sufficiently clean water, both in terms of quantity and quality, (2) the disposal of well-ordered 
wastewater so that it does not become a source of pollutants, (3) landfills made of waterproof material easy to clean, and has a lid. Poor hygiene conditions can affect the quality of food served to consumers. This obviously will also affect the level of health of consumers who consume these foods. If food sanitation hygiene is bad, it can lead to health problems such as foodborne disease and food poisoning cases. One disease caused by food and drink that does not meet health requirements is diarrheal disease (Yulia, 2016). Diseases that are closely related to the provision of unhygienic food and often occur are diseases with symptoms of diarrhea, gastrointestinal and food poisoning. One of the causes of food-borne diseases is the presence of Escherichia coli bacteria in water or food sources which is a sure indication of contamination of human feces. (Setyorini, 2013)

At least some canteen sanitation requirements can be identified by government regulations covering building, construction, and sanitation factors with the following details:

Building:

- Canteen building must sturdy, strong and permanent;

- The room must be arranged according to its function, making it easier for guests to flow, the flow of employees, the flow of food and ready-made food and other items that can pollute the food.

Construction:

- The floor must be waterproof, flat, not slippery, dry and clean;

- Wall; the surface of the wall must be flat, waterproof and cleaned;

- Ventilation; Natural ventilation must ensure adequate air circulation, can eliminate steam, gas, smoke, odor, and dust in the room. Artificial ventilation is needed if natural ventilation cannot meet the requirements;

- Lighting; the lighting intensity of each room must be sufficient to carry out effective food processing work and room cleaning activities;

- The roof does not leak, is quite gentle and does not become a nest of mice and other insects;

- Ceiling, flat surface, clean, no holes.

Sanitation Facilities:

- Clean water; the quality of clean water must meet physical requirements (odorless, tasteless, colorless, clear), and the amount is sufficient for all activities;

- Wastewater flows smoothly, the sewerage system must be good, the channels are made of water-proof material, the sewage disposal channel is closed;

- Toilet; Toilet available, clean. Inside the toilets must be available latrines, basins, and water tanks. Soap/detergent is available for hand washing. Inside the toilet, a tub and clean water must be available in sufficient condition;

- The trash can is made of waterproof material, not easily corroded, has a lid. Available at every place/space that produces waste. Waste is disposed of every 24 hours;

- Hand washing facilities, hand washing facilities are placed so that they are easily reached by guests and employees. Handwashing facilities are equipped with running water, soap/detergent, reservoirs whose surface is smooth, easy to clean and the waste are drained into a closed sewer;

- Washing equipment is made of materials that are strong, safe, not rusty and easy to clean. Washing tubs consist of at least 3 washbasins/washbasins which are to flush, soap and rinse. 7. A place to wash food ingredients made of materials that are strong, safe, not rusty and easy to clean. 8 . The storage of clean water (water reservoirs) must be closed so that it can withstand the entry of mice and insects.

Kitchen room, dining room, and presentation: the kitchen must be clean, the kitchen must be free of insects, mice, and other animals.

The results of the research by Agustina, Pambayun, \& Febry (2011) on food processing equipment can be concluded that only $34.8 \%$ of respondents had good sanitation equipment, while the remaining $65.2 \%$ of respondents had poor sanitation in terms of equipment. Based on observations during the study, none of the respondents who washed the equipment correctly found any research. Some respondents washed the equipment 
without using soap, the equipment was only dipped in a bucket of dirty washing water. The level of knowledge of food traders about good food safety is still relatively low, only $17.65 \%$. The level of knowledge about excessive doses of food coloring is $64 \%$ while $52 \%$ of traders know the dangers of formalin and borax. The low level of knowledge and sanitation practices is a challenge for Indonesian people, including in the canteen on higher education campus. Agreeing with this, Aminah \& Hidayah, (2006) emphasizes that knowledge about sanitation hygiene is not always balanced with the conditions of selling places that meet the requirements.

Canteens with closed rooms area or canteens with open spaces must have sufficient clean water supply, both for processing needs and for washing and cleaning needs. For water that will be used for cooking and stored in buckets, do not slurry the water by dipping your hands. Use a long stem to remove water from a bucket/container of water. The water bucket/container must always be closed. The water requirements for canteens are that water must be free of microbes and chemicals that can endanger a person's health, are colorless and smell. The water used must meet the quality requirements for clean water and no drinking water. As well as water that will be used for cooking or washing food, it must meet the requirements for raw water (Nuraida, 2011).

Both closed canteens and canteens in open spaces have the same requirements for the disposal of waste (liquid, solid and gas), with details as follows:

- Trash or solid waste in the canteen must be available and the amount is sufficient and always closed;

- Inside and outside the canteen must be free from the garbage. Distance to the canteen with a temporary trash shelter with a minimum of 20 meters;

- There are sewers or sewers, including wastewater and function properly and are easy to clean if there is a blockage;

- There is a vent that serves to drain fresh air and remove waste gas from cooking food (Nuraida, 2011).

Plurals occur in various canteens where the conditions for washing the equipment, there are still many who have not fulfilled the provisions as in Kepmenkes No. 1098 / MENKES / SK / VII / 2003 concerning Hygiene Requirements for Sanitation of Restaurants and Restaurants, which states that the requirements for washing facilities are consisting of 3 washing tubs that are useful for flushing, soaping, and rinsing. Thus, the washing place for the equipment must have a sufficient amount of water and washing soap available. Draining sites are needed to dry equipment without using a cloth/napkin to avoid cross-contamination or re-contamination of cleaned equipment. According to Kepmenkes No. 1098 / MENKES / SK / VII / 2003 concerning Hygiene Requirements for Sanitation of Restaurants and Restaurants, there are several conditions in serving food, among others: must be protected from pollution; equipment for presentation must be kept clean; must be contained and touched with clean equipment; and presentation is done with healthy behavior and clean clothes. (Syafirah \& Andrias, 2012). The other challenges, such as improper disposal of wastewater, are a trigger for health problems, so it needs to be addressed as early as possible. Wastewater from bathrooms, kitchens, and toilets contains various substances that endanger humans and living creatures around them. Efforts to improve environmental sanitation through the use of sewerage channels that meet health requirements can reduce the incidence of diarrhea. Food safety is a necessity of the community because safe foods will protect and prevent diseases or other health problems. Food safety is basically an effort to sanitize food, nutrition, and safety.

There is also a canteen where the trash does not use plastic bags for easy food scraps so that in the trash can it looks dirty and smelly because of the leftover rotting food. The rest of the wet food can stick to the surface of the trash that does not use a plastic bag and if this continues to occur it can occur a buildup of garbage on the surface of the trash. Poor waste management can be used as a place for developing disease vectors such as flies (Pawenang, 2017). According to data from BPOM in 2004, the university was the highest place for food poisoning cases in Indonesia, which amounted to $22.57 \%$. 12 The Malaysian 
Ministry of Health also stated that in $200717 \%$ of food poisoning cases occurred in the university area (Inayah, 2015).

\section{CONCLUSION}

Looking at the current phenomenon, attention to canteen sanitation is very important in an effort to realize a public health sector, because it requires the willingness of universities to formulate a variant policy so that it can implement good canteen sanitation, considering that no sanitation policy good will have a dangerous impact. The policy can be in the form of a rector's regulations or head of a college, the establishment of a canteen supervisory and fostering institution, provision of training and guidance for food providers or catering tenants. Without the awareness of the campus as canteen sanitation will not be implemented and even gives a greater risk to the decline in student health figures. In addition, as explained earlier, the requirements for canteen sanitation in accordance with the Ministry of Health include building factors, construction, and sanitation facilities, this must be truly applied in the effort to implement public health. In addition to canteen sanitation, there are several other things which of course must be considered, including hygiene or hygiene. Poor hygiene conditions can affect the quality of food served to consumers. If food sanitation hygiene is bad, it can lead to health problems such as foodborne disease and food poisoning cases. Therefore, the importance of implementing canteen sanitation policies in an effort to optimize the public health sector must be carried out properly so that the impact of the lack of attention to canteen sanitation within the university or campus is no longer happening.

\section{ACKNOWLEDGEMENTS}

This work would not have been possible without the financial support of the LPPM (Research and Community Service Institute) of Universitas Pembangunan Nasional "Veteran" Jawa Timur through the RISTI (Science and Technology Applied Research) scheme.

\section{REFERENCES}

1. Agustina, F., Pambayun, R. and Febry, F. (2011) Tradisional Di Lingkungan Sekolah Dasar Di Kelurahan Demang Lebar Daun Palembang Tahun 2009, Jurnal Publikasi IImiah Fakultas Kesehatan Masyarakat Universitas Sriwijaya.

2. Aminah, S. and Hidayah, N. (2006) 'Pengetahuan Keamanan Pangan Penjual Makanan Jajanan Di Lingkungan Sekolah Kelurahan Wonodri Kecamatan Semarang Selatan Kota Semarang', Jurnal Litbang Muhamadiyah Universitas Semarang, 4(3), pp. 18-25.

3. BPOM (2008) Peraturan Badan pengawas Obat dan Makanan Republik Indonesia, Badan Pengawas Obat dan Makanan. Jakarta.

4. Chusna, F. I. (2012) Faktor Yang Mempengaruhi Kualitas Sarana Sanitasi Kantin Di Universitas Negeri Semarang Tahun 2012. Universitas Negeri Semarang. doi: 10.15294/UJPH.V2I1.3036.

5. Gasim, H. (2015) 'Optimalisasi pelayanan kesehatan terhadap masyarakat miskin di provinsi gorontalo', Publik (Jurnal Ilmu Administrasi), 4(1).

6. Inayah (2015) 'Hubungan Pengetahuan Higiene Dan Sanitasi Makanan Terhadap Sikap Dan Perilaku Penjamah Makanan Di Kantin Universitas Tanjungpura', Jurnal Mahasiswa Fakultas Kedokteran Untan, 13(3), pp. 1576-1580.

7. Kartika, N. T. (2017) 'Evaluasi Promosi Dan Pelatihan Higiene Dan Sanitasi Penjamah Makanan Di Kantin Sekolah', Ikesma, 13(2), pp. 128-134.

8. Kemenkes (2006) Keputusan Menteri Kesehatan Republik Indonesia No 1429.

9. Mukono (2000) Prinsip-Prinsip Dasar Kesehatan Lingkungan. Airlangga University Pess.

10. Nadiawati (2013) Gambaran Higiene dan Sanitasi Kantin Kampus 2 Universitas Islam Negeri Alauddin Makassar. Universitas Islam Negeri Alauddin Makassar.

11. Nugroho, M. D. A. and Yudhastuti, R. (2014) 'Kondisi Higiene Penjamah Makanan dan 
Sanitasi Kantin di SMAN 15 Surabaya', Jurnal Kesehatan Lingkungan, 7(2), pp. 166-170. 12. Nuraida, L. (2011) Menuju Kantin Sehat di Sekolah. Bogor: Seafast Center.

13. Oihuwal, T. S. (2012) Gambaran Higiene dan Sanitasi Kantin Kampus di Lingkungan Universitas Islam Dalam Negeri Alauddin Makassar. Universitas Islam Negeri Alauddin Makassar.

14. Pawenang, E. (2017) 'Kondisi Sanitasi Dan Kepadatan Lalat Kantin Sekolah Dasar Wilayah Kerja Puskesmas Kedungmundu', Journal of Health Education, 2(1), pp. 66-72.

15. Rahmawati, S. et al. (2018) 'Sanitasi Makanan dan Minuman dengan Menggunakan Salmonella sp. sebagai Indikator di Kantin Universitas Islam Indonesia', Jurnal Sains dan Teknologi Lingkungan, 10(2).

16. Saputra, J. (2016) Studi Deskriftif Sanitasi Kantin dan Failitas Sanitasi Dasar Di Lingkungan Sekolah Dasar Pada Wilayah Kerja Puskesmas Ungaran Kecamatan Ungaran Barat, Kabupaten Semarang Tahun 2016. Universitas Negeri Semarang.

17. Sari, E. R. (2013) Gambaran Higiene dan Sanitasi Kantin Sekolah (Studi Banding SMPN Perkotaan dan SMPN Pedesaan Tahun 2013). Universitas Islam Negeri Alauddin Makassar.

18. Sari, N., Irnawati, M. and Indra, C. (2013) 'Higiene Sanitasi Pengelolaan Makanan Dan Perilaku Penjamah Makanan Di Kantin Sekolah Menengah Atas (Sma) Negeri Dan Swasta Di Kecamatan Rantau Utara Kabupaten Labuhan Batu Tahun 2012', Lingkungan dan Keselamatan Kerja, 2(1), pp. 43-50.

19. Setyorini, E. (2013) Hubungan Praktek Higiene Pedagang Dengan Keberadaan Escherichia Coli Pada Rujak. Universitas Negeri Semarang.

20. Supriadi, S. and Chandra, E. (2018) 'Penerapan Hygiene dan Sanitasi di Pondok Pesantren As'ad Seberang Kota Jambi Tahun 2016', Jurnal Ilmiah Universitas Batanghari Jambi, 18(1), pp. 132-142.

21. Syafirah, S. and Andrias, D. R. (2012) 'Higiene Penjamah Makanan dan Sanitasi Kantin Sekolah Dasar Negeri di Kecamatan Mulyorejo, Surabaya', Jurnal Media Gizi Indonesia, 10(02), pp. 111-116.

22. Ulfatin, E. M. R. N. and Triwiyanto, T. (2015) 'Manajemen Layanan Kantin Sehat Di Sekolah Adiwiyata (Studi Kasus Di Smpn 10 Malang)', Jurnal Administrasi Pendidikan, 2(1), pp. 1-15.

23. Undang Undang Nomor 36 Tahun 2009 Tentang Kesehatan (2009) Republik Indonesia.

24. Utami, R. A., Thoha, S. jaya and Nugraheni, I. L. (2018) 'Dampak Sanitasi Lingkungan terhadap Kesehatan Masyarakat di Wilayah Pesisir Kecamatan Kota Agung', Jurnal Penelitian Geografi, 6(7).

25. Wati, C. A. I. (2013) 'Faktor Yang Berhubungan Dengan Praktik Sanitasi Pada Pedagang Makanan Di Sekitar Pantai Logending Kecamatan Ayah Kabupaten Kebumen', Unnes Journal of Public Health, 2(4), pp. 1-10. doi: 10.1177/1403494814549494.

26. Yulia, Y. (2016) 'Higiene Sanitasi Makanan, Minuman dan Sarana Sanitasi terhadap Angka Kuman Peralatan Makan dan Minum pada Kantin', Jurnal Vokasi Kesehatan, 2(1), pp. 55-61. 